\title{
Expression of ADAMTS4 in Ewing's sarcoma
}

\author{
K. MINOBE ${ }^{1,2}$, R. ONO $^{1 *}$, A. MATSUMINE ${ }^{3 *}$, F. SHIBATA-MINOSHIMA ${ }^{2}$, K. IZAWA $^{2}$,

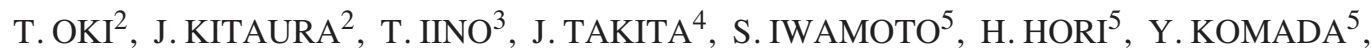

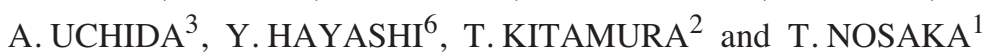

\begin{abstract}
${ }^{1}$ Department of Microbiology and Molecular Genetics, Mie University Graduate School of Medicine, Tsu; ${ }^{2}$ Division of Cellular Therapy, The Institute of Medical Science, The University of Tokyo, Tokyo; ${ }^{3}$ Department of Orthopaedic Surgery, Mie University Graduate School of Medicine, Tsu; ${ }^{4}$ Department of Cell Therapy and Transplantation Medicine, Graduate

School of Medicine, The University of Tokyo, Tokyo; ${ }^{5}$ Department of Pediatrics and Developmental Science,

Mie University Graduate School of Medicine, Tsu; ${ }^{6}$ Gunma Children's Medical Center, Gunma, Japan
\end{abstract}

Received March 29, 2010; Accepted May 18, 2010

DOI: 10.3892/ijo_00000706

\begin{abstract}
Ewing's sarcoma (EWS) is a malignant bone tumor that frequently occurs in teenagers. Genetic mutations which cause EWS have been investigated, and the most frequent one proved to be a fusion gene between EWS gene of chromosome 22 and the FLII gene of chromosome 11. However, a limited numbers of useful biological markers for diagnosis of EWS are available. In this study, we identified ADAMTS4 (a disintegrin and metalloproteinase with thrombospondin motifs) as a possible tumor marker for EWS using the retrovirus-mediated signal sequence trap method. ADAMTS4 is a secreted protein of 837 amino acids with a predicted molecular mass of $98-100 \mathrm{kDa}$. It is a member of metalloprotease family, is expressed mainly in cartilage and brain, and regulates the degradation of aggrecans. ADAMTS4 has been suggested to be involved in arthritic diseases and gliomas. Herein, we show that ADAMTS4 mRNA was expressed in all primary EWS samples and all EWS-derived cell lines examined, while its expression was detected only in small subpopulations of other solid tumors. Furthermore, ADAMTS4 expression was found to be regulated by EWS FLII fusion gene-dependent manner. We also demonstrated that ADAMTS4 protein was highly expressed in tumor samples of the patients with EWS by using immunohistochemistry. These results suggest that ADAMTS4 is a novel tumor marker for EWS.
\end{abstract}

Correspondence to: Dr T. Nosaka, Department of Microbiology and Molecular Genetics, Mie University Graduate School of Medicine, 2-174, Edobashi, Tsu 514-8507, Japan

E-mail: nosaka@doc.medic.mie-u.ac.jp

*Contributed equally

Key words: EWS-FLI1, tumor marker, signal sequence trap, retrovirus

\section{Introduction}

Ewing's sarcoma (EWS) is the second most frequent primary bone tumor of childhood and adolescence with aggressive clinical course and poor prognosis. It is recognized that EWS is a part of Ewing's sarcoma family of tumors (ESFTs) which also include the peripheral primitive neuroectodermal tumor (PNET) $(1,2)$, Askin's tumor and extraosseous EWS. Biologically, ESFTs are characterized by common chromosomal translocation between the 5' portion of the EWS gene (22q12) and the 3' portion of the members of the ETS family genes (3). More than $85 \%$ of the cases have the fusion gene EWSFLI1 due to $\mathrm{t}(11 ; 22)(\mathrm{q} 24 ; \mathrm{q} 12)(4,5)$. Five to $10 \%$ of the cases pocess $E W S$ - $E R G$ due to $\mathrm{t}(21 ; 22)(\mathrm{q} 22 ; \mathrm{q} 12)(6)$. The other rare cases are EWS-ETVI, EWS-EIAF and EWS-FEV, each resulting from $\mathrm{t}(7 ; 22)(\mathrm{p} 22 ; \mathrm{q} 12), \mathrm{t}(17 ; 22)(\mathrm{q} 12 ; \mathrm{q} 12)$ and $\mathrm{t}(2 ; 22)(\mathrm{q} 33 ; \mathrm{q} 12)$, respectively $(3,7,8)$. The EWS-ETS chimeric proteins behave as aberrant transcriptional regulators and are believed to play a crucial role in the onset and progression of the ESFTs $(9,10)$.

Currently, diagnosis of EWS is determined mainly by CD99 immunohistochemistry (11-13), and by genetic aberration. However, CD99 expression is also reported to be positive in some T cell acute lymphoblastic leukemia (T-ALL), acute myelogenous leukemia (AML), ependymoma, synovial sarcoma and pancreatic endocrine tumors (14-16). Besides, not all EWSs have this specific chromosomal translocation. Thus, there is no specific biomarker for differentiating EWS from other soft tissue sarcomas. Among the patients with localized tumor at diagnosis, $20 \%$ relapse within 4 years and die of the disease. In contrast, 5-year survival rate is $~ 20-30 \%$ in cases with metastasis. This study was performed to find a useful tumor marker for EWS.

The signal sequence trap (SST) is a strategy to identify complementary DNAs (cDNAs) containing signal sequence that encode secreted and type I membrane proteins (17). To date, various important molecules have been detected including $S D F-1$, a member of the tumor necrosis factor receptor superfamily TROY, Xenopus-Tsukushi, Vasorin and leukocyte mono-Ig-like receptor (LMIR) by the SST method 
(18-23). In this study, we identified a secreted molecule ADAMTS4 (a disintegrin and metalloproteinase with thrombospondin motifs) from EWS cell lines by using the SST system based on retrovirus-mediated expression screening (SST-REX) $(24,25)$.

ADAMTS is a family of proteinases which was first described in 1997 (26). Today, 19 different members of the ADAMTS family have been identified, but the functions, mechanisms of activation, and substrates of most members remain incompletely understood (27). Members of the $A D A M T S$ family are closely related to the $A D A M$ (a disintegrin and metalloproteinase) family, but unlike $A D A M s$, the ADAMTSs are secreted molecules, some of which bind to the extracellular matrix. ADAMTS4 was originally purified from chondrocytes and synovial cells stimulated with interleukin-1 (28). The structure of ADAMTS4 consists of six domains, a prodomain, a metalloproteinase domain, a disintegrin domain, a thrombospondin type I motif, a cysteine-rich domain and a spacer domain. It has been demonstrated to cleave the aggrecan at $\mathrm{Glu}^{373}-\mathrm{Ala}^{374}$, and therefore is also named as aggrecanase1 (29-32). The aggrecanase activity of ADAMTS4 is inhibited by TIMP-3 (tissue inhibitor of metalloproteinase-3) (33), which was originally identified as an inhibitor of matrix metalloproteinases. Yamanishi et al demonstrated that ADAMTS4 was overexpressed in synovial cells and chondrocytes in the patients with osteoarthritis (OA) and rheumatoid arthritis (RA) (34). Thus, ADAMTS4 is considered to play an important role in the aggrecan degradation of articular cartilage in OA and RA. Recent studies reported that ADAMTS4 cleaves not only aggrecan but also brevican, versican and $\alpha 2$-macroglobulin (35).

In this study, we have disclosed that ADAMTS4 mRNA was expressed in all tissue samples of EWS patients and all EWS cell lines examined, and the mRNA level of ADAMTS4 was regulated by EWS-FLII in the cell line. We have also demonstrated the ADAMTS4 protein expression by immunostaining of the patients' samples and the cell lines. Thus, we propose that ADAMTS4 is a possible tumor marker of EWS.

\section{Materials and methods}

Cell lines. Osteosarcoma cell lines (MG63, HOS, KHOS/NP, SaOS2 and U2OS), neuroblastoma cell lines (KPNSI-FA, LAN-1 and NB69), a lung cancer cell line H460, a liver cancer cell line PLC/PRF/5, a cholangiocarcinoma cell line HuCCT1, a colon cancer cell line SW-48, T-ALL cell lines (Jurkat, PEER, CEM and HPB-ALL), B-ALL cell lines (NALM16, NALM24 and IM9), AML cell lines (MOLM13 and ML1), an acute myelomonocytic leukemia cell line U937, EWS cell lines (SJES-2, SJES-3, SJES-5, SJES-6, SJES-7 and SJES-8), rhabdomyosarcoma cell lines (RMS and SJRH-30), pancreatic cancer cell lines (AsPC-1, BxPC-3 and Capan-1), glioblastoma cell lines (U87MG, U251 and T98G), and gastric cancer cell lines (HGC-27, MKN45, GCIY and KATO-III) were cultured in RPMI-1640 medium (Sigma-Aldrich, St. Louis, MO, USA) containing 10\% heatinactivated fetal bovine serum (FBS) (Sigma-Aldrich). A murine pro-B cell line $\mathrm{Ba} / \mathrm{F} 3$ was maintained in RPMI-1640 containing $10 \% \mathrm{FBS}$ and $1 \mathrm{ng} / \mathrm{ml}$ murine interleukin-3 (IL-3)
(R\&D Systems, Minneapolis, MN, USA). A retrovirus packaging cell line Plat-E (36) and NIH3T3 were cultured in Dulbecco's modified Eagle's medium (DMEM) (SigmaAldrich) containing 10\% FBS. Human mesenchymal stem/ progenitor cells (hMSCs) were purchased from Sanko Junyaku (Tokyo, Japan).

Patient samples and normal controls. Samples from 7 patients with EWS, 13 osteosarcoma, 4 chondrosarcoma, 4 synovial sarcoma, and 3 rhabdomyosarcoma, which were obtained at initial surgery at the department of orthopaedic surgery at Mie University Hospital, were examined by reverse transcription (RT)-PCR. Schwannoma, desmoid and lipoma samples were used as controls. Tissue samples for immunohistochemical staining were obtained from 25 EWS patients who underwent an open biopsy or a surgical resection. For enzyme-linked immunosorbent assay (ELISA), we used serum samples of 3 osteosarcomas, 1 osteofibrous dysplasia, 1 chondrosarcoma, 1 synovial sarcoma, 6 EWS and 4 healthy volunteers. Basically sera were isolated before the chemotherapy except for few cases. Informed consent was obtained from each patient or parent and volunteer. This study was approved by the ethics committee at Mie University.

Antibodies and other reagents. A rabbit polyclonal antiADAMTS4 antibody which was raised against amino acids 764-837 of human ADAMTS4 (Santa Cruz Biotechnology, Santa Cruz, CA, USA) and a horseradish peroxidase (HRP)conjugated goat anti-rabbit IgG secondary antibody (Bio-Rad Laboratories, Hercules, CA, USA) were used for immunoprecipitation (IP)-Western blot analysis. Immunostaining was performed by using the following antibodies: the same anti-ADAMTS4 antibody as used for IP-Western analysis, an $\mathrm{N}$-universal rabbit IgG (Dako, Kyoto, Japan), an HRPconjugated anti-rabbit IgG antibody (Nichirei Biosciences, Tokyo, Japan) for immunohistochemistry, and an Alexa488conjugated anti-rabbit IgG antibody (Invitrogen, Carlsbad, CA, USA) for immunofluorescence microscopy. For ELISA, a monoclonal anti-ADAMTS4 antibody raised against amino acids 213-685 of the recombinant human ADAMTS4 (R\&D Systems), a biotinylated goat anti-ADAMTS4 antibody raised against amino acids 213-685 of the recombinant human ADAMTS4 and an Avidin-HRP (eBioscience, San Diego, CA, USA) were used.

Screening of EWS cDNA library by SST. A human EWS cDNA library was screened by SST-REX as previously described $(24,25)$. Briefly, poly $(A)^{+}$RNA was prepared from EWS cell lines using the FastTrack2.0 Kit (Invitrogen). The cDNA was synthesized from the mixture of poly (A) ${ }^{+}$RNAs of 6 EWS cell lines with random hexamers, using the SuperScript Choice System (Invitrogen) according to the manufacturer's instructions. The synthesized cDNA was sizeseparated by electrophoresis on an agarose gel. Fractions greater than $500 \mathrm{bp}$ were collected and inserted into BstXI sites of pMX-SST (25) using BstXI adaptors (Invitrogen). $\mathrm{Ba} / \mathrm{F} 3$ cells were infected with the retroviruses expressing the EWS-derived cDNA library and selected for growth in the absence of IL-3. Genomic DNAs extracted from IL-3independent clones were subjected to PCR to recover the 
Table I. Primer sequences used in RT-PCR analyses in murine tissues.

\begin{tabular}{|c|c|c|}
\hline Gene & Sense & Antisense \\
\hline DKFZP56400823 & 5'-CCATTGCCTGTCTCTCTCATGACA-3' & 5'-GAGCTGTGCTCTTCTGTTGGTGA-3' \\
\hline ADAMTS4 & 5'-GAGCTGTGCTCTTCTGTTGGTGA-3' & 5'-CAGAGAAGCGAAGCGCTTGGTT-3' \\
\hline DNER & 5'-GACATAATCCTGCCCCGCTCT-3' & 5'-CTCTGATGGCTTCGTGGCACAT-3' \\
\hline NGFR & 5'-CGTGTTCTCCTGCCAGGACAA-3' & 5'-GCTGTGCAGTTTCTCTCCCTCT-3' \\
\hline LRRN6A & 5'-GTCTTCACCGGCCTCAGCAA-3' & 5'-CCCTCGATTGTACCGATTGGGTT-3' \\
\hline ECSM2 & 5'-GACAACTCAGACCTCGCAGGAA-3' & 5'-CATTGGCTGTGGAGCAGCTTTCA-3' \\
\hline LGALS3BP & 5'-CAGGACTACTGTGGACGGCTT-3' & 5'-CTACTCCAGGTGGAAGAGGTGTA-3' \\
\hline PTPRF & 5'-GCTGGCCCAGGAGAAGAGTT-3' & 5'-GCTCTGCCCATTGTACAGGATCTT-3' \\
\hline FCGRT & 5'-GCTGTGAACTGGCCTCGGATA-3' & 5'-CCAGCAATGACCATGCGTGGAA-3' \\
\hline LAMP2 & 5'-CGCTGTCTCTTGGGCTGTGAAT-3' & 5'-GGCACCTTCTCCTCAGTGATGTT-3' \\
\hline RCN1 & 5'-CTAAGCCCGGACGAGAGCAA-3' & 5'-GGCCATTGTCCTCGTGGGAA-3' \\
\hline MMP14 & 5'-CATGAGTTGGGGCATGCCCTA-3' & 5'-CGGCCAAGCTCCTTAATGTGCTT-3' \\
\hline SDC2 & 5'-CTCCATTGAGGAAGCTTCAGGAGT-3' & 5'-CTTCTGGTAAGCTGCGCTGGAT-3' \\
\hline DAG1 & 5'-GGAAGCCCACGGTCACCATT-3' & 5'-GCTTGAGCTTGTCGGTAGTGGTA-3' \\
\hline EPCR & 5'-GGCAACGCCTCTCTGGGAAAA-3' & 5'-CGGCCACACCAGCGATTATGAA-3' \\
\hline CD97 & 5'-CTGGAACAAAGCCTTCGGACCTT-3' & 5'-GTCGGTGTCCCAGTACCCATT-3' \\
\hline CD99L2 & 5'-GTCCAGAGAGGATATGGAGACACA-3' & 5'-GGTTCTGCAGACTGCGTTTCTTG-3' \\
\hline IGFBP5 & 5'-GCGACGAGAAAGCTCTGTCCAT-3' & 5'-GCCTTGTTCGGATTCCTGTCTCA-3' \\
\hline CLU & 5'-GAAGGCATTCCCGGAAGTGTGTA-3' & 5'-GCTGGACATCCATGGCCTGTT-3' \\
\hline LSAMP & 5'-GCTCTGGAATACAGCCTCCGAA-3' & 5'-GTGTCATCCCGGTACCACTCAA-3' \\
\hline NPTN & 5'-GTAACCTCACTTCCAGCTCTCACA-3' & 5'-GGAGGCAGAGCCAATGGAGTT-3' \\
\hline EFNA5 & 5'-GCAGCAACCCCAGATTCCAGA-3' & 5'-GATGGCTCGGCTGACTCATGTA-3' \\
\hline PODXL & 5'-CCTTCACCAGTAGCAGTGGACAA-3' & 5'-CCACTGTAGACGCCATAGACTGT-3' \\
\hline TMEM123 & 5'-CCACTCAGTGCTGACCTCCAA-3' & 5'-GTTCGTCAATGCTTCGGTACCGAA-3' \\
\hline GAPDH & 5'-CAGTATGACTCCACTCACGGCAA-3' & 5'-CAGATCCACGACGGACACATTG-3' \\
\hline
\end{tabular}

integrated cDNAs using vector primers. The resulting PCR fragments were sequenced and analyzed.

RT-PCR analysis. RT-PCR was carried out to detect ADAMTS4 transcript in tumor cell lines, murine tissues and patients' samples. Total RNA was isolated with acid guanidiumphenol-chloroform method, and then $5 \mu \mathrm{g}$ RNA was reversetranscribed to cDNA in a total volume of $33 \mu \mathrm{l}$ with random hexamers by using the Ready-To-Go You-Prime First-Strand Beads (GE Healthcare UK, Buckinghamshire, UK). RT-PCR was performed with the programmable cyclic reactor under the following conditions: denaturation at $94^{\circ} \mathrm{C}$ for $3 \mathrm{~min}$ followed by 30 cycles of amplification $\left(94^{\circ} \mathrm{C}\right.$ for $30 \mathrm{sec}, 60^{\circ} \mathrm{C}$ for $30 \mathrm{sec}$, and $72^{\circ} \mathrm{C}$ for $45 \mathrm{sec}$ ). PCR product was separated by $1-2 \%$ agarose gel electrophoresis and visualized by ethidium bromide staining. The primers used for RT-PCR was described in Tables I and II.

Cloning of the full-length cDNA encoding ADAMTS4. Fulllength ADAMTS4 was generated as follows. The first half of ADAMTS4 (1-1194 bp) was isolated from pMX-SST vector by digestion with BamHI. Based on the sequence data, the last half (1195-2514 bp) were amplified by PCR from cDNAs of the EWS cell line SJES-5, and digested with BamHI and NotI. The fragment was subcloned into a pMXs-puro retroviral vector (37). The resultant vector was digested with $B a m \mathrm{HI}$, and then ligated with the Bam HI fragment of the first half of ADAMTS4. The primers used for amplification are as follows: SST5', 5'-GGGGGTGGACCATCCTCTA-3'; SST3', 5'-CGCGCAGCTGTAAACGGTAG-3'; ADAMTS4-FL-S, 5'-GAAAGAATTCGCTGCAGTACCAGTGCCATG-3'; ADAMTS4-FL-S2, 5'-GAGCACCTCTCGCCATGTCA-3'; ADAMTS4-FL-AS, 5'-GAAAGAGAATTCGCGGCC GCTTATTTCCTGCCCGCCCAGG-3'; ADAMTS4-AS2, 5'-CTTTGGATCCACATGAGCCATCACAGGGGCCA TGACATGGCGAGAGGTGCTCAAAGGCCCATTCAAA CTGATGCATG-3'.

Transfection and infection. Retroviral transfection was done as described previously $(36,37)$. Briefly, retroviruses were generated by transient transfection of Plat-E packaging cells (36) with FuGENE 6 (Roche Diagnostics, Basel, Switzerland). $\mathrm{Ba} / \mathrm{F} 3$ and NIH3T3 cells were infected with the retroviruses in the presence of $10 \mu \mathrm{g} / \mathrm{ml}$ polybrene. Selection with G418 or puromycin was started $48 \mathrm{~h}$ after infection.

Small interfering (si)RNA design and transfection experiments. EWS-FLII-specific siRNA (siEF1) for SJES-5 cell line was designed as previously described (38). As a negative control, siGFP was employed (Hayashi-Kasei, Osaka, Japan). 
Table II. Primer sequences used in RT-PCR analyses in human cancer cell lines.

\begin{tabular}{|c|c|c|}
\hline Gene & Sense & Antisense \\
\hline DKFZP56400823 & 5'-CCATCTGGACTAGCTCTCCACA-3' & 5'-GTGCTGGTCACAGTGGAGCTA-3' \\
\hline ADAMTS4 & 5'-GTGGAGTCTCCACTTGCGACA-3' & 5'-CCAGGGCGAGTGTTTGGTCT-3' \\
\hline DNER & 5'-GTGGTGAAGGTCAGCACCTGT-3' & 5'-GGCTGAGGGCACAGAAGTCAA-3' \\
\hline NGFR & 5'-GTTCTCCTGCCAGGACAAGCA-3' & 5'-GTCCACGGAGATGCCACTGT-3' \\
\hline LRRN6A & 5'-GTACAАCCTCAAGTCACTGGAGGT-3' & 5'-CATTGAGCACGCGCAGGTAGTT-3' \\
\hline ECSM2 & 5'-CAATGACCCAGACCTCTAGCTCT-3' & 5'-GCAGCTTTCAGACAGCCCTGA-3' \\
\hline LGALS3BP & 5'-CCCACAGACCTGCTCCAACT-3' & 5'-CCGTCTGGACTGATAGACCAGTT-3' \\
\hline PTPRF & 5'-CAGCCCCTACTCGGATGAGAT-3' & 5'-GCGATGACATTCGCATAGCGGTT-3' \\
\hline FCGRT & 5'-СТСТСССТССТGTACСАCСТT-3' & 5'-GTGCCCTGCTTGAGGTCGAAAT-3' \\
\hline LAMP2 & 5'-GTGCAGTTCGGACCTGGCTT-3' & 5'-CAGCTGCCTGTGGAGTGAGTT-3' \\
\hline $\mathrm{RCN} 1$ & 5'-GACAATGATGGGGATGGCTTTGTCA-3' & 5'-CGGAATTCGTTAAACTGCTCCCGTT-3' \\
\hline MMP14 & 5'-CAACATTGGAGGAGACACCCACTTT-3' & 5'-GTTCCAGGGACGCCTCATCAAA-3' \\
\hline SDC2 & 5'-GCTCCATTGAAGAAGCTTCAGGAGT-3' & 5'-GCCTTCTGATAAGCAGCACTGGAT-3' \\
\hline DAG1 & 5'-CGGAGGCAGATCCATGCTACA-3' & 5'-GGCAGTTTCCAATCTGGTGATGGA-3' \\
\hline EPCR & 5'-CTACTTCCGCGACCCCTATCA-3' & 5'-GCGAAGTGTAGGAGCGGCTT-3' \\
\hline CD97 & 5'-CAAGACAAGCTCAGCCGAGGT-3' & 5'-CTCCCCATCGGAGGACTCAA-3' \\
\hline CD99L2 & 5'-CAAGAAACCCAGTGCTGGGGAT-3' & 5'-GTACGCTGAACAGCTGGCTCT-3' \\
\hline IGFBP5 & 5'-CTCAACGAAAAGAGCTACCGCGA-3' & 5'-CTGTCGAAGGTGTGGCACTGAA-3' \\
\hline CLU & 5'-CAATGAGACCATGATGGCCCTCT-3' & 5'-CCGGGCTATGGAAGTGGATGT-3' \\
\hline LSAMP & 5'-GGACAACATCACCGTGAGGCA-3' & 5'-GGAGACCTCGTTGGCAGCTT-3' \\
\hline NPTN & 5'-CCCTGTCACCCTGCAGTGTA-3' & 5'-CCAATGGCGTTGGTGGCATTACA-3' \\
\hline EFNA5 & 5'-CCAGAGGGGTGACTACCATATTGA-3' & 5'-CGGCTGACTCATGTACGGTGT-3' \\
\hline PODXL & 5'-CTCCACAGCCACAGCTAAACCTA-3' & 5'-CTGGCAGGGTAGGTGTTCTCAA-3' \\
\hline TMEM123 & 5'-CCATGGCGGCATCTGCAAACAT-3' & 5'-CGATACCGAATGCCTCTTCTTGAGT-3' \\
\hline PCOLCE & 5'-CGGACGCTTTTGTGGGACCTT-3' & 5'-GGCAGCTTGACTTTAGGCTCAGTT-3' \\
\hline SEZ6L2 & 5'-GCACCTGCACTTTGAAAGGGTCT-3' & 5'-GTCCCCTTCCCGCACATTCAATAT-3' \\
\hline IGFBP4 & 5'-GAAGCCCCTGCACACACTGAT-3' & 5'-GAAAGCTGTCAGCCAGCTGGT-3' \\
\hline IGFBP3 & 5'-GCATCTACACCGAGCGCTGT-3' & 5'-GGGACTCAGCACATTGAGGAACTT-3' \\
\hline LOX & 5'-GTCACTGGTTCCAAGCTGGCTA-3' & 5'-GGAATATCTTGGTCGGCTGGGTA-3' \\
\hline CTGF & 5'-GCGTGTGCACCGCCAAAGAT-3' & 5'-CGGTATGTCTTCATGCTGGTGCA-3' \\
\hline SPARC & 5'-CTGCCAGAACCACCACTGCAA-3' & 5'-CTGCCAGTGTACAGGGAAGATGT-3' \\
\hline QSCN6 & 5'-GGCTGACCTGGAATCTGCACT-3' & 5'-CATTGTGGCAGGCAGAACAAAGTTC-3' \\
\hline EDIL3 & 5'-CTGTGAGTGCCCAGGCGAATTTA-3' & 5'-GATTTCATACCCAGAGGCTCAGAACA-3' \\
\hline MXRA8 & 5'-GTACACCTGCAACCTGCACCAT-3' & 5'-GGGACGATGACATTGATGACGTTGT-3' \\
\hline PRRT3 & 5'-GCTGACAGTCACAGGAACTCTGA-3' & 5'-GCCTCCTGCAAGTGTTCCTCAA-3' \\
\hline LRP1 & 5'-CAATGGCCTGACGCTGGACTAT-3' & 5'-CGGTGTCACACTTCCACCAGA-3' \\
\hline ISLR & 5'-GCTCGCTGCAACTCAACCACAA-3' & 5'-CTCAGCACTGCCCAGCTCATT-3' \\
\hline COL6A1 & 5'-GCAGTACAGCCACAGCCAGAT-3' & 5'-GTCAAAGTTGTGGCTGCCCAC-3' \\
\hline TIMP1 & 5'-GACCTCGTCATCAGGGCCAA-3' & 5'-GCAAGGTGACGGGACTGGAA-3' \\
\hline LAMP1 & 5'-CACGTTACAGCGTCCAGCTCAT-3' & 5'-CCTTGTAGGAAAAACCGGCTAGAAC-3' \\
\hline SERPINH1 & 5'-CTGCTGCGCTCACTCAGCAA-3' & 5'-CGTGATGGGGCATGAGGATGAT-3' \\
\hline COL1A1 & 5'-CACCTCAAGAGAAGGCTCACGAT-3' & 5'-CCACGCTGTTCTTGCAGTGGTA-3' \\
\hline GAPDH & 5'-ACCACAGTCCATGCCATCAC-3' & 5'-TCCACCACCCTGTTGCTGTA-3' \\
\hline
\end{tabular}

The RNA sequences used are as follows: siEF1 (sense 5'-GGC AGCAGAACCCUUCUUAdCdG-3', antisense 5'-UAAGA AGGGUUCUGCUGCCdCdG-3'). SJES-5 cells were plated on a 6-well plate and propagated in RPMI-1640 medium supplemented with $10 \%$ FBS. Twenty-four hours later, for transfection, $1 \mu \mathrm{l}$ of 10 pmol siRNA was diluted with $99 \mu 1$ of Opti-MEM (Invitrogen), and $2 \mu \mathrm{l}$ of siFECTOR reagent (B-Bridge International, Mountain View, CA, USA) was diluted with $98 \mu \mathrm{l}$ of Opti-MEM. Both solutions were mixed gently and incubated at room temperature for $5 \mathrm{~min}$. The mixture was diluted with $800 \mu 1$ of Opti-MEM, and left at room temperature for $15 \mathrm{~min}$. Next, $1 \mathrm{ml}$ of RNA/liposome 
Table III. Genes isolated by the retrovirus-mediated signal sequence trap method (SST-REX).

\begin{tabular}{|c|c|c|}
\hline Isolated gene & Accession number ${ }^{a}$ & Frequency ${ }^{\mathrm{b}}$ \\
\hline Granulin (GRN) & NM_002087 & 22 \\
\hline Alzheimer disease amyloid $B$ A4 precursor protein & NM_201414 & 16 \\
\hline Procollagen-proline, 2-oxoglutarate 4-dioxygenase & NM_000918 & 14 \\
\hline NODAL modulator 2 (NOMO2) & NM_173614 & 12 \\
\hline NODAL modulator 1 (NOMO1) & NM_014287 & 12 \\
\hline NODAL modulator 3 (NOMO3) & NM_001004067 & 11 \\
\hline Golgi apparatus protein 1 (GLG1) & NM_012201 & 10 \\
\hline Podocalyxin-like (PODXL) & NM_001018111 & 6 \\
\hline Lysosomal-associated membrane protein 2 (LAMP2) & NM_013995 & 6 \\
\hline Insulin-like growth factor binding protein 3 (IGFBP3) & NM_000598 & 6 \\
\hline Basigin & NM_198589 & 6 \\
\hline Dystroglycan 1 & NM_004393 & 6 \\
\hline DKFZP56400823 protein & NM_015393 & 5 \\
\hline Ephrin-A5 & NM_001962 & 4 \\
\hline SPARC & NM_003118 & 4 \\
\hline CD97 & NM_001025160 & 4 \\
\hline Calreticulin & NM_004343 & 4 \\
\hline Insulin-like growth factor binding protein 4 (IGFBP4) & NM_001552 & 4 \\
\hline Poliovirus receptor & NM_006505 & 3 \\
\hline Syndecan 2 & NM_002998 & 3 \\
\hline Seizure-related 6 homolog like 2 & NM_201575 & 3 \\
\hline CD276 & NM_025240 & 3 \\
\hline TMED7 & NM_181836 & 3 \\
\hline Ribophorin II & NM_002951 & 3 \\
\hline Niemann-Pick disease, type $\mathrm{C} 1$ & NM_000271 & 3 \\
\hline TMEM165 & NM_018475 & 3 \\
\hline MHC class I antigen & NM_005514 & 3 \\
\hline Colony stimulating factor 2 & NM_000758 & 3 \\
\hline NGFR & NM_002507 & 2 \\
\hline Ribophorin I & NM_002950 & 2 \\
\hline Proline-rich transmembrane protein 3 & NM_207351 & 2 \\
\hline Custerin & NM_203339 & 2 \\
\hline Prosaposin & NM_002778 & 2 \\
\hline Leucine rich repeat neuronal 6A (LRRN6A) & NM_032808 & 2 \\
\hline Lysosomal-associated membrane protein 1 (LAMP1) & NM_005561 & 2 \\
\hline Quiescin Q6 & NM_001004128 & 2 \\
\hline Neuroplastin & NM_017455 & 2 \\
\hline Reticulocalbin 1 & NM_002901 & 2 \\
\hline Hemicentin 1 & NM_031935 & 2 \\
\hline Matrix metallopeptidase 14 (MMP14) & NM_004995 & 2 \\
\hline Collagen, type VI, $\alpha 1$ & NM_001848 & 2 \\
\hline MHC class I polypeptide-related sequence A & NM_000247 & 2 \\
\hline Low density lipoprotein-related protein 1 (LRP1) & NM_002332 & 2 \\
\hline TMEM123 & NM_052932 & 2 \\
\hline Collagen, type XV, $\alpha 1$ & NM_001855 & 2 \\
\hline Protein kinase $\mathrm{C}$ substrate $80 \mathrm{~K}-\mathrm{H}$ & NM_002743 & 2 \\
\hline EGF-like module containing, mucin-like, hormone receptor-like 2 & NM_152920 & 2 \\
\hline Collagen, type I, $\alpha 2$ & NM_000089 & 2 \\
\hline Lectin, galactoside-binding, soluble, 3 binding protein & NM_005567 & 2 \\
\hline Collagen, type VII, $\alpha 1$ & NM_000094 & 2 \\
\hline
\end{tabular}


Table III. Continued.

\begin{tabular}{|c|c|c|}
\hline Isolated gene & Accession number ${ }^{\mathrm{a}}$ & Frequency ${ }^{\mathrm{b}}$ \\
\hline Protein tyrosine phosphatase, receptor type, $\mathrm{F}$ & NM_130440 & 1 \\
\hline Connective tissue growth factor & NM_001901 & 1 \\
\hline Protein disulfide isomerase family $\mathrm{A}$, member 4 & NM_004911 & 1 \\
\hline Immunoglobulin superfamily containing leucine-rich repeat (ISLR) & NM_005545 & 1 \\
\hline Collagen, type I, $\alpha 1$ & NM_000088 & 1 \\
\hline Procollagen C-endopeptidase enhancer (PCOLCE) & NM_002593 & 1 \\
\hline Chromosome 1 open reading frame 56 & NM_017860 & 1 \\
\hline TIMP metallopeptidase inhibitor 1 (TIMP1) & NM_003254 & 1 \\
\hline Insulin-like growth factor binding protein 5 (IGFBP5) & NM_000599 & 1 \\
\hline Solute carrier family 24 member 6 (SLC24A6) & NM_024959 & 1 \\
\hline Neural cell adhesion molecule 2 (NCAM2) & NM_004540 & 1 \\
\hline Collagen, type V, $\alpha 1$ & NM_000093 & 1 \\
\hline CD248 & NM_020404 & 1 \\
\hline Fc fragment of IgG, receptor, transporter, $\alpha$ & NM_004107 & 1 \\
\hline Nucleobindin 1 & NM_006184 & 1 \\
\hline delta/notch-like EGF-related receptor (DNER) & NM_139072 & 1 \\
\hline Limbic system-associated membrane protein (LSAMP) & NM_002338 & 1 \\
\hline Lysyl oxidase (LOX) & NM_002317 & 1 \\
\hline Endothelial cell-specific molecule 2 (ECSM2) & NM_001077693 & 1 \\
\hline Isolate Tor36 (ZE657) mitochondrion & AY738975 & 1 \\
\hline Lectin, mannose-binding, 1 & NM_005570 & 1 \\
\hline CD99 molecule-like 2 & NM_031462 & 1 \\
\hline EGF-like repeats and discoidin I-like domains 3 & NM_005711 & 1 \\
\hline SIL1 homolog, endoplasmic reticulum chaperone & NM_022464 & 1 \\
\hline ADAM with thrombospondin type 1 motif, 4 (ADAMTS4) & NM_005099 & 1 \\
\hline Matrix-remodelling associated 8 (MXRA8) & NM_032348 & 1 \\
\hline Protein $\mathrm{C}$ receptor, endothelial & NM_006404 & 1 \\
\hline Tissue factor pathway inhibitor & NM_001032281 & 1 \\
\hline Serpin peptidase inhibitor, clade H member 1 (SERPINH1) & NM_001235 & 1 \\
\hline Protocadherin $\gamma$ subfamily A.6 & NM_032086 & 1 \\
\hline
\end{tabular}

${ }^{\mathrm{a} A c c e s s i o n}$ number in GenBank protein database. ${ }^{\mathrm{b}}$ Number of the clones isolated by SST-REX.

complex was added to $1 \mathrm{ml}$ of OPTI-MEM supplemented with $20 \%$ FBS. Then, the culture medium of the SJES- 5 cells was replaced with the $2 \mathrm{ml}$ of the RNA/liposome-containing medium prepared. Twenty-four hours after transfection, culture medium was replaced with the $2 \mathrm{ml}$ of Opti-MEM with $10 \% \mathrm{FBS}$, and grown for another $48 \mathrm{~h}$. The cells were harvested and then total RNA was extracted for RT-PCR analysis. The primers used for RT-PCR are as follows: EWSFLI1-S, 5'-GGGTATGGCACTGGTGCTTATGAT-3'; EWSFLI1-AS, 5'-GGCTCCAAAGAAGCTGGAGGAA-3'; EWS-S, 5'-GCCCAGCCCACTCAAGGATAT-3'; EWS-AS, 5'-CCC CTGTGCTAGATTGAGGTTGA-3'; FLI1-S, 5'-GCCAACG CCAGCTGTATCA-3'; FLI1-AS, 5'-GTGTGAAGGCACGT GGGTGTT-3'.

IP-Western analysis. IP-Western blot analysis was performed as previously described (39) with some modifications. Briefly, cells were lysed in RIPA buffer [50 mM Tris- $\mathrm{HCl}$
(pH 7.4), $150 \mathrm{mM} \mathrm{NaCl}, 1 \%$ NP40, 0.5\% deoxycholate, $0.1 \%$ SDS]. Cell lysates were immunoprecipitated with the rabbit polyclonal anti-ADAMTS4 antibody. SDS-polyacrylamide gel electrophoresis was performed under reducing conditions using 5-20\% gradient gel (Wako Pure Chemical Industries, Osaka, Japan). After transfer to a nitrocellulose membrane, the blot was probed with the rabbit polyclonal anti-ADAMTS4 antibody and then with the HRP-conjugated goat anti-rabbit $\mathrm{IgG}$ secondary antibody. ADAMTS4 protein was detected with enhanced chemiluminescence (ECL) Western blotting detection reagents (Santa Cruz Biotechnology).

Immunohistochemical staining. Specimens were retrieved from the patients during surgical resection. Archival tumor blocks were fixed with $10 \%$ formaldehyde/phosphate-buffered saline (PBS), and embedded in paraffin. The paraffinembedded tissues, measuring $4 \mu \mathrm{m}$ in thickness, were placed on glass slides (Matsunami Glass, Osaka, Japan) and deparaf- 
Table IV. Comparison of the gene expression levels between human mesenchymal stem cells (hMSCs) and Ewing's sarcoma (EWS) cells.

\begin{tabular}{lcc}
\hline A. & hMSC & EWS \\
\hline DKFZP56400823 & - & + \\
ADAMTS4 & - & + \\
DNER & - & + \\
NGFR & - & + \\
LRRN6A & - & + \\
ECSM2 & - & + \\
LGALS3BP & - & + \\
PTPRF & - & + \\
FCGRT & - & + \\
\hline B. & & EWS
\end{tabular}

\section{B}

\begin{tabular}{lccc}
\hline LAMP2 & + & $<$ & ++ \\
RCN1 & + & $<$ & + \\
MMP14 & + & $<$ & + \\
SDC2 & + & $<$ & + \\
DAG1 & + & $<$ & + \\
EPCR & + & $<$ & + \\
CD97 & + & $<$ & + \\
CD99L2 & + & $<$ & + \\
IGFBP5 & + & $<$ & + \\
CLU & + & $<$ & + \\
LSAMP & + & $<$ & + \\
NPTN & + & $<$ & + \\
EFNA5 & + & $<$ & + \\
PODXL & + & $<$ & + \\
TMEM123 & + & $<$ & + \\
\hline C. & & & + \\
\hline
\end{tabular}

$\begin{array}{lll}\text { C. hMSC } & \text { EWS }\end{array}$

\begin{tabular}{lcrr}
\hline PCOLCE & + & & + \\
SEZ6L2 & + & & + \\
IGFBP4 & + & + \\
IGFBP3 & + & + & + \\
LOX & + & $>$ & + \\
CTGF & + & $>$ & + \\
SPARC & + & & + \\
QSCN6 & + & & + \\
EDIL3 & + & & + \\
MXRA8 & + & & + \\
PRRT3 & + & & + \\
LRP1 & + & & + \\
ISLR & + & & + \\
COL6A1 & + & & + \\
TIMP1 & ++ & + \\
LAMP1 & + & & + \\
SERPINH1 & + & & + \\
COL1A1 & + & & + \\
\hline
\end{tabular}

++ , strongly positive; + , modelately positive; - , negative; $>$ or $<$, $>2$-fold difference in the expression level. finized in xylene for hematoxylin and eosin (H\&E) and immunohistochemical staining. Antigen retrieval was performed with citrate buffer ( $\mathrm{pH} 6.0$ ) at $97^{\circ} \mathrm{C}$ for $45 \mathrm{~min}$. After cooling for $60 \mathrm{~min}$ and washing in PBS, the rabbit anti-ADAMTS4 antibody (Santa Cruz Biotechnology) diluted 1:50 in antibody diluent buffer (Dako) was reacted. The slides were then washed and incubated with the HRP-conjugated anti-rabbit IgG antibody. The 3-3' diaminobenzidine tetrahydrochloride (DAB) was used for coloration. Hematoxylin was used as the final nuclear counterstaining.

Immunofluorescence staining. The expression of ADAMTS4 protein was analyzed by immunofluorescence. Cells were fixed for $30 \mathrm{~min}$ in $4 \%$ paraformaldehyde/PBS, and permeabilized for $30 \mathrm{~min}$ in $0.1 \%$ Triton X/PBS. Fixed cells were rehydrated with Tris-buffered saline, and then incubated with the rabbit polyclonal anti-ADAMTS4 antibody. Immunofluorescence staining was done with the Alexa488-conjugated anti-rabbit IgG antibody. Nucleus was detected with bisbenzimide (Hoechst-33342, Sigma-Aldrich) staining.

ELISA. To evaluate the expression level of secreted ADAMTS4 protein, supernatants of the EWS cell lines and the patient sera were subjected to ELISA. The 96-well plates were coated with the monoclonal anti-human ADAMTS4 antibody at $4^{\circ} \mathrm{C}$ overnight. After 3 washes with washing buffer (0.05\% Tween-20/PBS), the plates were treated with $10 \%$ FBS in PBS for $1 \mathrm{~h}$ at room temperature. The recombinant human ADAMTS4 (amino acids 213-685) diluted with 10\% FBS in PBS, as standard proteins, and the samples were added to each well, and incubated at room temperature for 2 h. After 5 washes with washing buffer, the Avidin-HRP and the biotinylated anti-human ADAMTS4 detection antibody were added to each well, and incubated for $1 \mathrm{~h}$ at room temperature. After 7 washes with washing buffer, $100 \mu 1$ of tetramethylbenzidine buffer as a substrate was added to each well and incubated for $30 \mathrm{~min}$ at room temperature in the dark. Color development was stopped by addition of $100 \mu 1$ of stop solution $\left(1 \mathrm{~N} \mathrm{H}_{3} \mathrm{PO}_{4}\right)$. Optic density of each sample was measured at $450 \mathrm{~nm}$.

\section{Results}

Analysis of isolated cDNA clones. In SST-REX screening, we isolated 322 factor-independent $\mathrm{Ba} / \mathrm{F} 3$ clones (Table III). Sequencing analyses revealed that integrations derived from 256 clones harbored the signal sequence. Among them, 80 different secreted and type I membrane proteins were identified. We used the database of RefEX, PubMed, ONCOMINE and SMART for the analysis, and 42 proteins that might be related to tumor/cancer onset and progression were selected.

Recent studies have suggested that the origin of EWS is derived from hMSC $(40,41)$. To examine the expression levels of these 42 molecules in EWS in comparison with hMSC, we performed RT-PCR analysis (Table IV). They were classified into 3 groups by mRNA expression profiles; the first group with high expression levels only in EWS (Table IVA), the second group with higher expression levels in EWS than in hMSC (Table IVB), and the third group with similar or lower expression levels in EWS compared with 
Table V. Gene expression levels in murine tissues by RT-PCR analysis.

\begin{tabular}{|c|c|c|c|c|c|c|c|c|c|c|c|c|c|c|}
\hline & Brain & Heart & Lung & Liver & Kidney & Spl & Stm & S. int & L. int & Mus & Tes & Thy & $\mathrm{BM}$ & $\mathrm{OC}$ \\
\hline DKFZP56400823 & + & + & + & - & + & + & + & + & + & + & + & + & + & + \\
\hline ADAMTS4 & ++ & + & - & + & - & - & - & - & - & + & - & - & + & + \\
\hline DNER & ++ & - & - & - & - & - & - & - & - & - & + & - & - & + \\
\hline NGFR & + & + & - & + & + & - & - & - & - & - & - & - & - & - \\
\hline LRRN6A & ++ & - & - & - & - & + & - & + & + & + & + & + & + & + \\
\hline ECSM2 & + & + & + & + & + & - & + & - & - & + & + & + & + & + \\
\hline LGALS3BP & + & + & + & + & + & + & ++ & ++ & + & + & ++ & ++ & + & + \\
\hline PTPRF & + & + & + & + & + & - & + & + & + & + & + & + & - & - \\
\hline FCGRT & + & + & + & + & + & + & + & + & + & + & + & + & + & + \\
\hline LAMP2 & + & ++ & + & + & ++ & ++ & + & + & + & + & + & + & + & + \\
\hline RCN1 & + & + & + & + & + & - & + & - & - & - & + & + & + & + \\
\hline MMP14 & + & + & + & + & + & - & + & - & - & + & + & + & + & + \\
\hline SDC2 & + & + & + & + & + & - & + & + & - & + & + & + & + & + \\
\hline DAG1 & + & + & + & + & + & + & + & + & + & + & + & + & + & + \\
\hline EPCR & + & + & + & + & + & + & + & - & - & + & + & + & + & ++ \\
\hline CD97 & + & + & + & + & + & + & + & + & + & + & + & + & + & + \\
\hline CD99L2 & + & + & + & + & + & - & - & - & - & + & + & + & + & + \\
\hline IGFBP5 & + & + & + & + & + & + & + & + & + & + & + & + & + & + \\
\hline CLU & + & + & + & + & + & + & + & + & - & + & + & + & + & + \\
\hline LSAMP & ++ & + & - & + & + & - & + & - & - & - & + & + & + & + \\
\hline NPTN & + & + & + & + & + & - & + & + & + & + & + & + & + & + \\
\hline EFNA5 & + & + & + & + & + & - & + & + & + & - & + & + & - & - \\
\hline PODXL & + & + & + & + & + & - & - & - & - & + & - & - & + & - \\
\hline TMEM123 & - & + & - & + & + & - & - & - & - & + & - & - & - & - \\
\hline
\end{tabular}

Spl, spleen; stm, stomach; s. int, small intestine; 1. int, large intestine; mus, muscle; tes, testis; thy, thymus; BM, bone marrow; OC, osteoclast; ++ , strongly positive; +, modelately positive; - , negative.

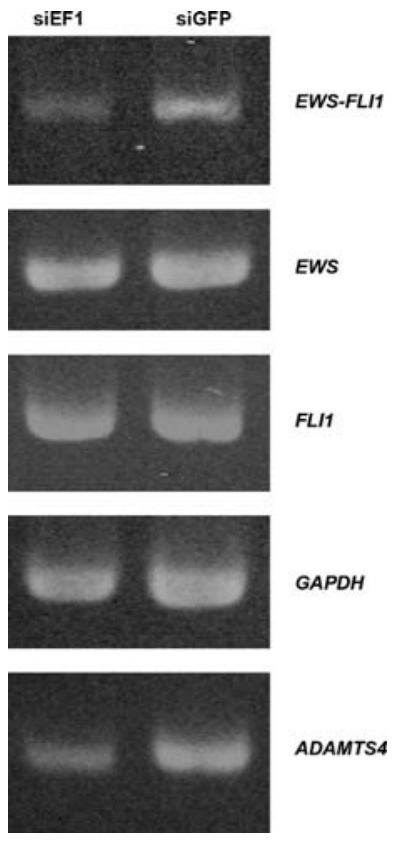

Figure 1. Effects of EWS-FLI1 suppression on ADAMTS4 expression. RNA from Ewing's sarcoma cells treated with either siEF1 or siGFP were subjected to RT-PCR experiment. ADAMTS4 mRNA expression was downregulated after treatment with EWS-FLII-specific siRNA. GAPDH (glyceraldehyde 3-phosphate dehydrogenase) was used as an internal control.
hMSC (Table IVC). We picked up 24 molecules from the first and second groups, and examined the expression patterns in murine organs. As shown in Table V, most molecules did not exhibit interesting tissue distribution patterns. However, some of the molecules attracted us by their expression profiles or their novelty as a gene. We focused on 5 molecules: ADAMTS4, DNER (delta/notch-like EGF-related receptor), NGFR (nerve growth factor receptor), LRRN6A (leucine rich repeat neuronal $6 A$ ) and ECSM2 (endothelial cell-specific molecule 2). We then examined expression levels of these 5 molecules in various solid tumor and hematopoietic cell lines by RT-PCR. As shown in Table VI, expression levels of ADAMTS4 were higher in EWS, glioblastoma and neuroblastoma in comparison with other cell lines. These results suggested that ADAMTS4 is one of the first candidate molecules as a marker for EWS among the SST clones.

ADAMTS4 expression is upregulated by EWS-FLII. Previous studies indicated the expression of the fusion gene, EWS$F L I 1$, was suppressed by using antisense oligonucleotide or siRNA. To decrease the expression level of EWS-FLII in the EWS cell line, we made an siRNA duplex specifically directed against the fusion junction of EWS-FLII transcript. EWS-FLII-specific siRNA (siEF1) was used for SJES-5 cell line. As a control, siGFP was also used. Transfection of siEF1, 
Table VI. Gene expression levels of ADAMTS4, DNER, NGFR, LRRN6A and ECSM2 in human cancer cell lines by RT-PCR analysis.

\begin{tabular}{|c|c|c|c|c|c|}
\hline & ADAMTS4 & DNER & NGFR & LRRN6A & ECSM2 \\
\hline AsPC-1 & - & - & + & - & - \\
\hline BxPC-3 & - & + & - & - & - \\
\hline Capan-1 & - & - & - & - & - \\
\hline U87MG & + & + & - & - & - \\
\hline $\mathrm{U} 251$ & + & ++ & - & - & - \\
\hline T98G & - & + & - & - & - \\
\hline HGC-27 & + & - & + & + & - \\
\hline MKN45 & - & + & - & ++ & - \\
\hline GCIY & + & + & - & + & - \\
\hline KATOIII & - & - & - & - & - \\
\hline MG63 & - & + & + & + & + \\
\hline HOS & + & + & + & + & + \\
\hline KHOS/NP & - & + & + & + & + \\
\hline $\mathrm{SaOS} 2$ & - & + & + & - & - \\
\hline U2OS & - & + & + & + & - \\
\hline KPNSI-FA & + & ++ & + & + & - \\
\hline LAN-1 & + & + & + & + & - \\
\hline NB69 & ++ & - & + & + & + \\
\hline $\mathrm{H} 460$ & + & ++ & - & + & - \\
\hline $\mathrm{PLC} / \mathrm{PRF} / 5$ & - & + & + & + & + \\
\hline HuCCT1 & - & ++ & - & + & + \\
\hline SW48 & - & + & + & - & + \\
\hline RMS & ++ & ++ & + & ++ & + \\
\hline SJRH-30 & ++ & + & + & + & + \\
\hline SJES-2, 3, 5, 6, 7, 8 & ++ & ++ & + & ++ & ++ \\
\hline MOLM13 & - & - & - & - & - \\
\hline ML1 & - & - & - & - & - \\
\hline U937 & - & - & - & - & + \\
\hline Jurkat & - & - & - & - & + \\
\hline PEER & - & - & - & - & + \\
\hline CEM & ++ & - & - & - & + \\
\hline HPB-ALL & - & - & - & - & - \\
\hline NALM24 & + & + & - & - & + \\
\hline NALM16 & - & + & + & - & - \\
\hline IM9 & - & - & + & - & + \\
\hline
\end{tabular}

++ , strongly positive; + , moderately positive; - , negative.

but not siGFP, led to significant decrease of the expression level of the EWS-FLII fusion transcript (Fig. 1). In agreement with the specificity of siEF1 against the EWS-FLI1 fusion gene, the expression level of EWS or FLII was not affected. Interestingly, suppression of EWS-FLII expression resulted in decreased expression of ADAMTS4 transcript. These results suggested that $A D A M T S 4$ expression was upregulated by EWS-FLI1.

Immunohistochemical analysis on ADAMTS4 protein expression. In order to confirm the expression of ADAMTS4 in EWS at the protein level, we stained 25 tissue samples derived from EWS patients with the anti-ADAMTS4 antibody together with the H\&E staining. ADAMTS4 protein was detected in 10 EWS samples, but not in 15 samples where tumors disappeared by chemotherapy (Fig. 2 and data not shown).

Next, to examine the subcellular localization of ADAMTS4, we stained EWS cell lines with the antiADAMTS4 antibody. Immunofluorescence microscopy revealed that ADAMTS4 protein was expressed mainly in the cytoplasm of EWS cell lines (Fig. 3C and D) and of the 

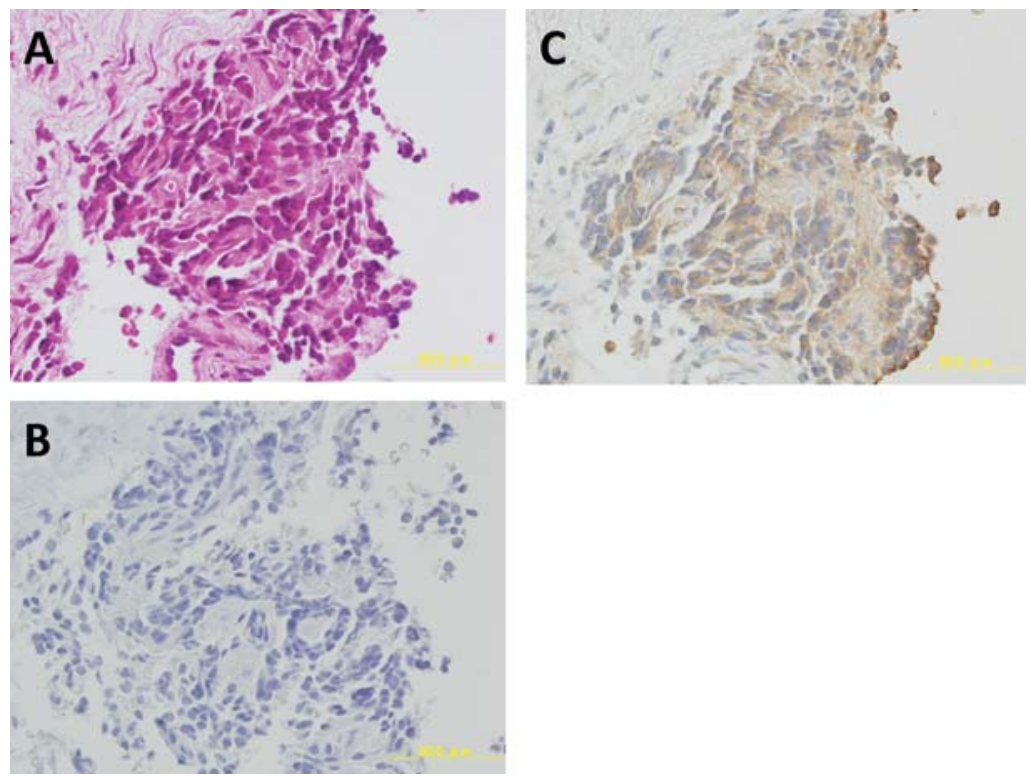

Figure 2. Immunohistochemical analysis of ADAMTS4 protein in the tissue section of the patient with Ewing's sarcoma. (A) Hematoxylin and eosin staining, (B) rabbit IgG, (C) anti-ADAMTS4 antibody.
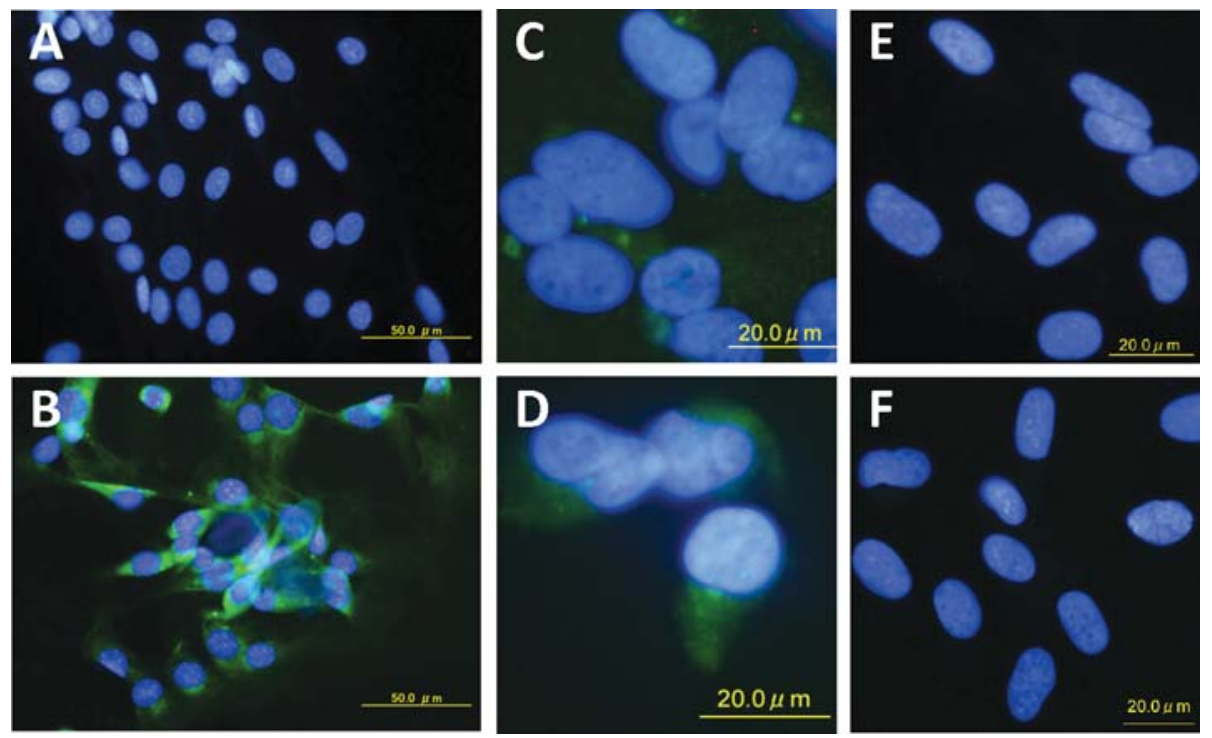

Figure 3. Immunofluorescence staining of ADAMTS4 protein in Ewing's sarcoma cell lines (SJES-2 and SJES-5), osteosarcoma cell lines (MG63 and SaOS2) and NIH3T3 cells expressing ADAMTS4. (A) NIH3T3, (B) ADAMTS4/NIH3T3, (C) SJES-5, (D) SJES-2, (E) MG63, (F) SaOS2.

NIH3T3 cells expressing human ADAMTS4 (Fig. 3B). In contrast, ADAMTS4 was not detected in osteosarcoma cell lines MG63 and SaOS2 (Fig. 3E and F), which did not express ADAMTS4 at the transcription level (Table VI).

ADAMTS4 is secreted from EWS cells. We next asked whether ADAMTS4 was secreted from EWS cells. First the immunoprecipitates of the cell lysates of EWS cell lines and positive and negative control cells with the anti-ADAMTS4 antibody were electrophoresed, blotted and probed with the same antibody. ADAMTS4 was detcted in EWS cells and the positive control cells as double bands of $\sim 100 \mathrm{kDa}$ (Fig. 4A). We next performed the same experiments using $2 \mathrm{ml}$ each of the supernatants of these cells. Notably, significant levels of expression of ADAMTS4 protein were observed in the supernatants of EWS cells and ADAMTS4/NIH3T3 cells (Fig. 4B). These results suggested that ADAMTS4 was secreted.

Comparative study of ADAMTS4 gene expression in 5 types of sarcomas. We showed that ADAMTS4 transcripts were expressed in EWS, osteosarcoma and rhabdomyosarcoma cell lines (Table VI). However, whether ADAMTS4 transcripts are expressed in tumor tissue samples remained unknown. Therefore, we tested if ADAMTS4 was expressed in soft tissue sarcomas and bone tumors including osteosarcoma, EWS, chondrosarcoma, synovial sarcoma and rhabdomyosarcoma (Fig. 5). Benign tumors including lipoma, desmoid 


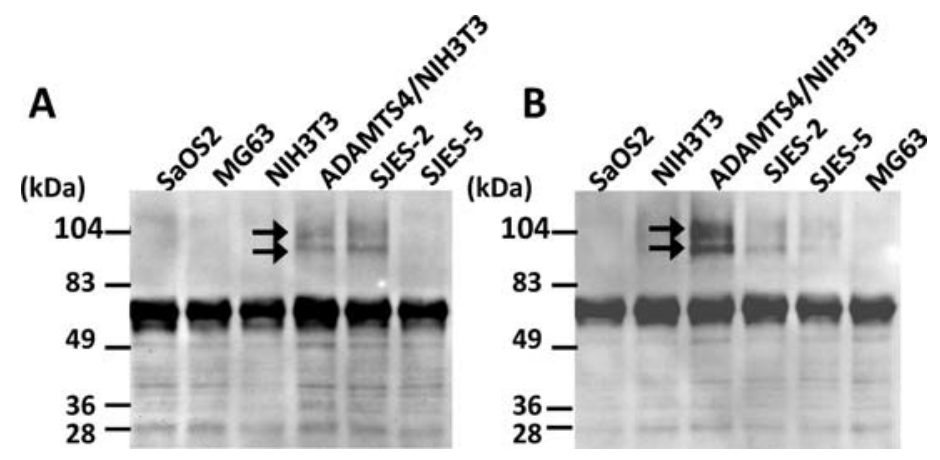

Figure 4. Detection of secreted ADAMTS4 protein. The cell lysates or culture supernatants were immunoprecipitated with the anti-ADAMTS4 antibody, resolved by SDS-PAGE, blotted and probed with the anti-ADAMTS4 antibody. Molecular size markers are shown on the left. Arrows indicate the ADAMTS4 proteins. (A), cell lysates; (B), supernatants.
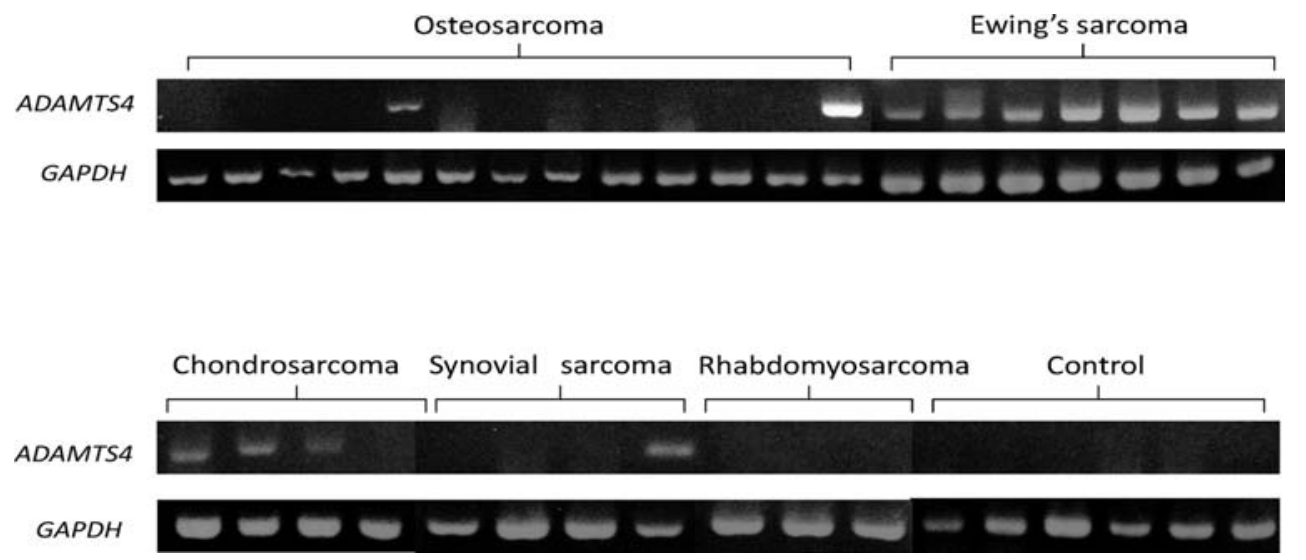

Figure 5. RT-PDR analysis of ADAMTS4 expression in the patient samples. GAPDH expression was used as an internal control.

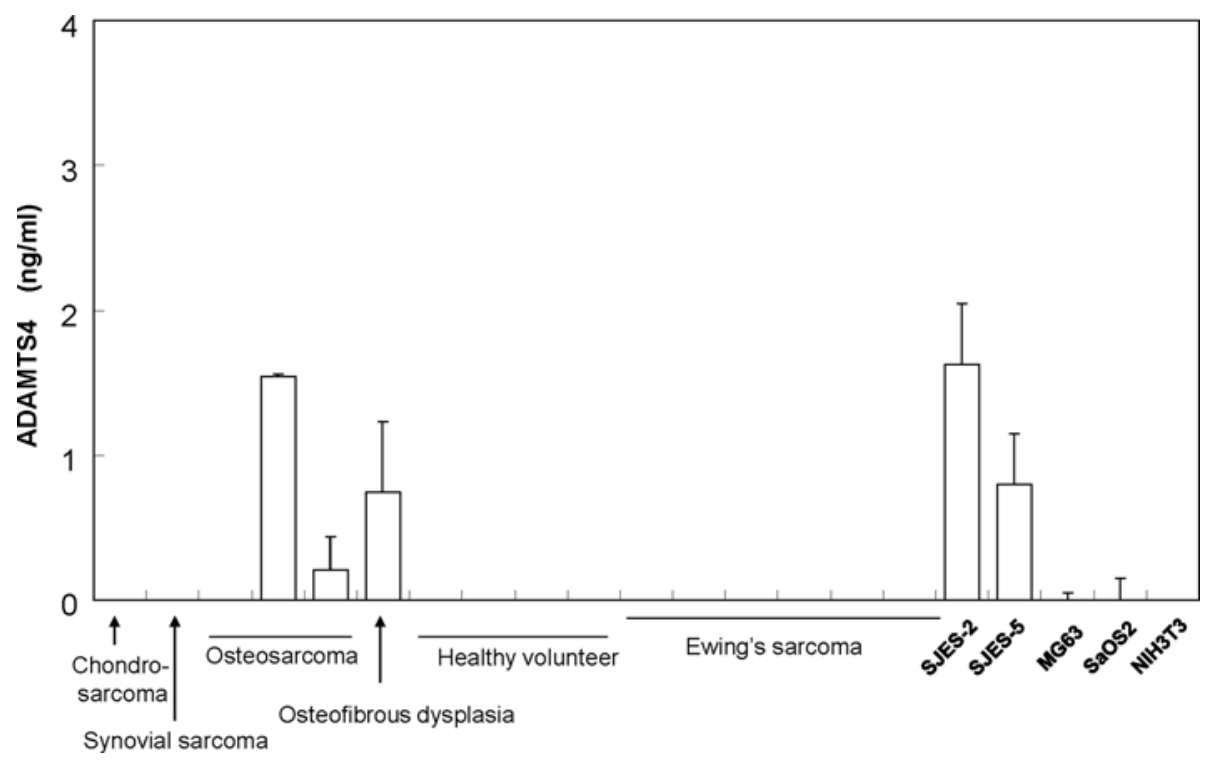

Figure 6. ELISA of ADAMTS4 protein in the patient sera and the supernatants of the cell lines. The error bars represent 1 standard deviation.

and Schwannoma were also examined as controls. In all 7 EWS samples, ADAMTS4 transcripts were highly expressed. Three out of 4 samples of chondrosarcoma moderately expressed ADAMTS4. This result was predictable, since
ADAMTS4 is expressed in normal cartilage cells. Also, 2 out of 13 samples of osteosarcoma and 1 out of 4 samples of synovial sarcoma expressed ADAMTS4. ADAMTS4 transcripts were not detected in the 3 samples of rhabdomyo- 
sarcoma, while those were highly expressed in rhabdomyosarcoma cell lines RMS and SJRH-30 (Table VI). Benign tumors examined did not express ADAMTS4.

No detection of secreted ADAMTS4 protein in the patient sera. To evaluate the amount of secreted ADAMTS4 protein in the patients, we analyzed ADAMTS4 protein levels in sera by ELISA. In agreement with the results described above, ADAMTS4 was detected in culture supernantants of EWS cell lines SJES-2 and SJES-5 (Fig. 6). The concentration of ADAMTS4 in SJES-2 cells was about twice as high as that in SJES-5 cells. For a positive control, culture supernatant of the NIH3T3/ADAMTS4 cells was also measured $(39.9 \mathrm{ng} / \mathrm{ml}$, data not shown). It is noteworthy that ADAMTS4 protein was detected in 2 out of 3 cases of osteosarcoma and in the only case of osteofibrous dysplasia. Consistent with the very high level of ADAMTS4 transcript shown in the extreme right lane among osteosarcoma samples in Fig. 5, serum from the same patient showed the high level of ADAMTS4 protein in ELISA as shown in Fig. 6 (middle lane among osteosarcoma samples). The other positive samples of osteosarcoma in both figures are not derived from the same patient, because only either serum or RNA was available in these two patients. ADAMTS4 protein was not detected in the 6 EWS patient sera examined. These results indicated that ADAMTS4 is expressed and secreted in EWS cells, but that the ADAMTS4 protein in the serum is not suitable as a marker for EWS.

\section{Discussion}

EWS is an aggressive neoplasm with a strong propensity to spread into neighboring tissues. Many patients are diagnosed at advanced stages of EWS. Since EWS has worse prognosis than other soft-tissue sarcomas, it is clinically important to distinguish EWS from other sarcomas. The reason for the poor prognosis in EWS patients is suggested to be that the micro-metastases are formed before clinical symptoms arise and tumors are detected (42). Currently, diagnosis of EWS is determined mainly by CD99 expression or by genetic aberrations that are exemplified by EWS-FLII fusion gene. Since both markers show lack of sensitivity, specificity or feasibility, more useful biomarkers such as surface antigens or secreted proteins are required in clinical areas.

In the present study, we searched for membrane and secreted proteins derived from EWS cell lines using the retrovirus-mediated signal sequence trap method SST-REX, and identified ADAMTS4 as a possible EWS marker. We demonstrated that ADAMTS4 was expressed in EWS cell lines and tissue samples derived from EWS patients. Interestingly, expression of ADAMTS4 was correlated with expression of EWS-FLI1, which is a hallmark of EWS. In addition, we demonstrated that ADAMTS4 was secreted from EWS cells, although we could not detect ADAMTS4 in serum samples derived from EWS patients.

It should be noted that two cases of the osteosarcoma patient samples were found to express high levels of ADAMTS4. It is tempting to speculate that a subclass of osteosarcoma with different property may exist.

In conclusion, we identified ADAMTS4 as a possible marker of EWS by using SST-REX. This is the first report to show the correlation between ADAMTS4 and EWS. Although ADAMTS4 protein in the serum could not be used as a biomarker for EWS, our study suggested that RNA transcripts of ADAMTS4 in the tissue sections are useful markers of EWS. Further studies will be required to determine the usefulness of this molecule in differential diagnosis and/or evaluation of the disease activity in clinical settings.

\section{Acknowledgements}

We gratefully thank Ms. S. Shoma (The University of Tokyo) for technical support and Dr Y. Murakami (The University of Tokyo) and Dr Y. Fukuchi (Keio University) for helpful comments on this study. This work was supported by a Grant-in-Aid for Cancer Research from the Ministry of Health, Labour and Welfare of Japan.

\section{References}

1. Jaffe R, Santamaria M, Yunis EJ, Tannery NH, Agostini RM, Medina J Jr and Goodman M: The neuroectodermal tumor of bone. Am J Surg Pathol 8: 885-898, 1984.

2. Hashimoto H, Enjoji M, Nakajima T, Kiryu H and Daimaru Y: Malignant neuroepithelioma (peripheral neuroblastoma). A clinicopathologic study of 15 cases. Am J Surg Pathol 7: 309-318, 1983.

3. Khoury JD: Ewing sarcoma family of tumors. Adv Anat Pathol 12: 212-220, 2005.

4. Turc-Carel C, Philip I, Berger MP, Philip T and Lenoir G: Chromosomal translocation $(11 ; 22)$ in cell lines of Ewing's sarcoma. C R Seances Acad Sci III 296: 1101-1103, 1983.

5. Zucman J, Delattre O, Desmaze C, et al: Cloning and characterization of the Ewing's sarcoma and peripheral neuroepithelioma $\mathrm{t}(11 ; 22)$ translocation breakpoints. Genes Chromosomes Cancer 5: 271-277, 1992.

6. Sorensen PH, Lessnick SL, Lopez-Terrada D, Liu XF, Triche TJ and Denny CT: A second Ewing's sarcoma translocation, $\mathrm{t}(21 ; 22)$, fuses the EWS gene to another ETS-family transcription factor, ERG. Nat Genet 6: 146-151, 1994.

7. Jeon IS, Davis JN, Braun BS, Sublett JE, Roussel MF, Denny CT and Shapiro DN: A variant Ewing's sarcoma translocation $(7 ; 22)$ fuses the EWS gene to the ETS gene ETV1. Oncogene 10: 1229-1234, 1995.

8. Arvand A and Denny CT: Biology of EWS/ETS fusions in Ewing's family tumors. Oncogene 20: 5747-5754, 2001.

9. May WA, Gishizky ML, Lessnick SL, Lunsford LB, Lewis BC, Delattre O, Zucman J, Thomas G and Denny CT: Ewing sarcoma 11;22 translocation produces a chimeric transcription factor that requires the DNA-binding domain encoded by FLI1 for transformation. Proc Natl Acad Sci USA 90: 5752-5756, 1993.

10. Ohno T, Rao VN and Reddy ES: EWS/Fli-1 chimeric protein is a transcriptional activator. Cancer Res 53: 5859-5863, 1993.

11. Jambhekar NA, Bagwan IN, Ghule P, Shet TM, Chinoy RF, Agarwal S, Joshi R and Amare Kadam PS: Comparative analysis of routine histology, immunohistochemistry, reverse transcriptase polymerase chain reaction, and fluorescence in situ hybridization in diagnosis of Ewing family of tumors. Arch Pathol Lab Med 130: 1813-1818, 2006.

12. Llombart-Bosch $A$ and Navarro S: Immunohistochemical detection of EWS and FLI-1 proteinss in Ewing sarcoma and primitive neuroectodermal tumors: comparative analysis with CD99 (MIC-2) expression. Appl Immunohistochem Mol Morphol 9: 255-260, 2006.

13. Bernstein M, Kovar H, Paulussen M, Randall RL, Schuck A, Teot LA and Juergens H: Ewing's sarcoma family of tumors: current management. Oncologist 11: 503-519, 2006.

14. Folpe AL, Hill CE, Parham DM, O'Shea PA and Weiss SW: Immunohistochemical detection of FLI-1 protein expression: a study of 132 round cell tumors with emphasis on CD99-positive mimics of Ewing's sarcoma/primitive neuroectodermal tumor. Am J Surg Pathol 24: 1657-1662, 2000.

15. Bernard G, Zoccola D, Deckert M, Breittmayer JP, Aussel C and Bernard A: The E2 molecule (CD99) specifically triggers homotypic aggregation of $\mathrm{CD}^{+} \mathrm{CD}^{+}$thymocytes. $\mathrm{J}$ Immunol 154: 26-32, 1995 . 
16. Zhang PJ, Barcos M, Stewart CC, Block AW, Sait S and Brooks JJ: Immunoreactivity of MIC2 (CD99) in acute myelogenous leukemia and related diseases. Mod Pathol 13: 452-458, 2000

17. Tashiro K, Tada H, Heilker R, Shirozu M, Nakano T and Honjo T: Signal sequence trap: a cloning strategy for secreted proteins and type I membrane proteins. Science 261: 600-603, 1993.

18. Shirozu M, Nakano T, Inazawa J, Tashiro K, Tada H, Shinohara T and Honjo T: Structure and chromosomal localization of the human stromal cell-derived factor 1 (SDF1) gene. Genomics 28: 495-500, 1995

19. Kojima T, Morikawa Y, Copeland NG, Gilbert DJ, Jenkins NA, Senba E and Kitamura T: TROY, a newly identified member of the tumor necrosis factor receptor superfamily, exhibits a homology with Edar and is expressed in embryonic skin and hair follicles. J Biol Chem 275: 20742-20747, 2000.

20. Ohta K, Lupo G, Kuriyama S, Keynes R, Holt CE, Harris WA, Tanaka $\mathrm{H}$ and Ohnuma S: Tsukushi functions as an organizer inducer by inhibition of BMP activity in cooperation with chordin. Dev Cell 7: 347-358, 2004.

21. Ikeda Y, Imai Y, Kumagai H, Nosaka T, Morikawa Y, Hisaoka T, Manabe I, Maemura K, Nakaoka T, Imamura T, Miyazono K, Komuro I, Nagai R and Kitamura T: Vasorin, a transforming growth factor beta-binding protein expressed in vascular smooth muscle cells, modulates the arterial response to injury in vivo. Proc Natl Acad Sci USA 101: 10732-10737, 2004.

22. Izawa K, Kitaura J, Yamanishi Y, Matsuoka T, Oki T, Shibata F, Kumagai H, Nakajima H, Maeda-Yamamoto M, Hauchins JP, Tybulewicz VL, Takai T and Kitamura T: Functional analysis of activating receptor LMIR4 as a counterpart of inhibitory receptor LMIR3. J Biol Chem 282: 17997-18008, 2007.

23. Ganju RK, Brubaker SA, Meyer J, Dutt P, Yang Y, Qin S, Newman W and Groopman JE: The alpha-chemokine, stromal cell-derived factor-1alpha, binds to the transmembrane G-proteincoupled CXCR-4 receptor and activates multiple signal transduction pathways. J Biol Chem 273: 23169-23175, 1998.

24. Kitamura T, Onishi M, Kinoshita S, Shibuya A, Miyajima A and Nolan GP: Efficient screening of retroviral cDNA expression libraries. Proc Natl Acad Sci USA 92: 9146-9150, 1995

25. Kojima T and Kitamura T: A signal sequence trap based on a constitutively active cytokine receptor. Nat Biotechnol 17: 487-490, 1999.

26. Kuno K, Kanada N, Nakashima E, Fujiki F, Ichimura F and Matsushima K: Molecular cloning of a gene encoding a new type of metalloproteinase-disintegrin family protein with thrombospondin motifs as an inflammation associated gene. J Biol Chem 272: 556-562, 1997.

27. Porter S, Clark IM, Kevorkian L and Edwards DR: The ADAMTS metalloproteinases. Biochem J 386: 15-27, 2005.

28. Tortorella MD, Burn TC, Pratta MA, et al: Purification and cloning of aggrecanase-1: a member of the ADAMTS family of proteins. Science 284: 1664-1666, 1999.

29. Tortorella MD, Malfait AM, Deccico C and Arner E: The role of ADAM-TS4 (aggrecanase-1) and ADAM-TS5 (aggrecanase-2) in a model of cartilage degradation. Osteoarthritis Cartilage 9: 539-552, 2001

30. Sandy JD, Neame PJ, Boynton RE and Flannery CR: Catabolism of aggrecan in cartilage explants. Identification of a major cleavage site within the interglobular domain. J Biol Chem 266: 8683-8685, 1991.
31. Sandy JD, Flannery CR, Neame PJ and Lohmander LS: The structure of aggrecan fragments in human synovial fluid. Evidence for the involvement in osteoarthritis of a novel proteinase which cleaves the Glu 373-Ala 374 bond of the interglobular domain. J Clin Invest 89: 1512-1516, 1992.

32. Lohmander LS, Neame PJ and Sandy JD: The structure of aggrecan fragments in human synovial fluid. Evidence that aggrecanase mediates cartilage degradation in inflammatory joint disease, joint injury, and osteoarthritis. Arthritis Rheum 36: 1214-1222, 1993.

33. Kashiwagi M, Tortorella M, Nagase H and Brew K: TIMP-3 is a potent inhibitor of aggrecanase 1 (ADAM-TS4) and aggrecanase 2 (ADAM-TS5). J Biol Chem 276: 12501-12504, 2001.

34. Yamanishi Y, Boyle DL, Clark M, Maki RA, Tortorella MD, Arner EC and Firestein GS: Expression and regulation of aggrecanase in arthritis: the role of TGF-beta. J Immunol 168: $1405-1412,2002$

35. Matthews RT, Gary SC, Zerillo C, Pratta M, Solomon K, Arner EC and Hockfield S: Brain-enriched hyaluronan binding (BEHAB)/brevican cleavage in a glioma cell line is mediated by a disintegrin and metalloproteinase with thrombospondin motifs (ADAMTS) family member. J Biol Chem 275: 22695-22703, 2000.

36. Morita S, Kojima T and Kitamura T: Plat-E: an efficient and stable system for transient packaging of retroviruses. Gene Ther 7: 1063-1066, 2000.

37. Kitamura T, Koshino Y, Shibata F, Oki, T, Nakajima H, Nosaka T and Kumagai H: Retrovirus-mediated gene transfer and expression cloning: powerful tools in functional genomics. Exp Hematol 11: 1007-1014, 2003.

38. Prieur A, Tirode F, Cohen P and Delattre O: EWS/FLI-1 silencing and gene profiling of Ewing cells reveal downstream oncogenic pathways and a crucial role for repression of insulin-like growth factor binding protein 3. Mol Cell Biol 24: 7275-7283, 2004.

39. Nosaka T, Kawashima T, Misawa K, Ikuta K, Mui AL and Kitamura T: STAT5 as a molecular regulator of proliferation, differentiation and apoptosis in hematopoietic cells. EMBO J 18: 4754-4765, 1999 .

40. Tirode F, Laud-Duval K, Prieur A, Delorme B, Charbord P and Delattre O: Mesenchymal stem cell features of Ewing tumors. Cancer Cell 11: 421-429, 2007.

41. Riggi N, Cironi L, Provero P, Suva ML, Kaloulis K, GarciaEcheverria C, Hoffmann F, Trumpp A and Stamenkovic I: Development of Ewing's sarcoma from primary bone marrowderived mesenchymal progenitor cells. Cancer Res 65: 11459-11468, 2005.

42. Schleiermacher G, Peter M, Oberlin O, Philip T, Rubie H, Mechinaud F, Sommelet-Olive D, Landman-Parker J, Bours D, Michon J and Delattre O: Increased risk of systemic relapses associated with bone marrow micrometastasis and circulating tumor cells in localized Ewing tumor. J Clin Oncol 21: 85-91, 2003. 